\title{
Human gut microbiota: the links with dementia development
}

\author{
Rashad Alkasir ${ }^{1}$, Jing $\mathrm{Li}^{1}$, Xudong $\mathrm{Li}^{2}$, Miao $\mathrm{Jin}^{2}$, Baoli Zhu ${ }^{1,3 凶}$ \\ ${ }^{1}$ Institute of Microbiology, Chinese Academy of Sciences, Beijing 100101, China \\ ${ }^{2}$ China-Japan Friendship Hospital, Beijing 100029, China \\ ${ }^{3}$ Collaborative Innovation Centre for Diagnosis and Treatment of Infectious Diseases, The First Attainted Hospital College of \\ Medicine, Zhejiang University, Hangzhou 310058, China \\ $\triangle$ Correspondence: zhubaoli@im.ac.cn (B. Zhu)
}

Received July 21, 2016 Accepted September 28, 2016

\begin{abstract}
Dementia is a comprehensive category of brain diseases that is great enough to affect a person's daily functioning. The most common type of dementia is Alzheimer's disease, which makes most of cases. New researches indicate that gastrointestinal tract microbiota are directly linked to dementia pathogenesis through triggering metabolic diseases and low-grade inflammation progress. A novel strategy is proposed for the management of these disorders and as an adjuvant for psychiatric treatment of dementia and other related diseases through modulation of the microbiota (e.g. with the use of probiotics).
\end{abstract}

KEYWORDS dementia, alzheimer's disease, gut microbiota, inflammation, probiotics

\section{INTRODUCTION}

Dementia is a syndrome that affects memory and other cognitive functions to the extent that it interferes with daily function. There are many conditions that can cause dementia, including neurodegenerative disorders [e.g. Alzheimer's disease (AD) and Parkinson's disease (PD)], cerebrovascular disease, brain injury, and certain infections. $A D$ is the most prevalent neurodegenerative disorder and the leading cause of dementia worldwide, accounting for approximately $60 \%-70 \%$ of all cases (Irizarry, 2001; Fratiglioni, 2001). AD is a highly incapacitating disorder, progressing from minor memory problems to a complete loss of mental functions and in the long run, resulting in death. The symptoms of $A D$ are caused by a progressive loss of cholinergic function due to neuronal cell death in the hippocampus cerebral cortex and different regions of the brain which regulate thought process and memory. Furthermore, the neuropathological hallmarks of $A D$ consist of two kinds of protein aggregates, amyloid beta $(A \beta)$ plaques and hyperphosphorylated tangles of tau-protein. $A \beta$ is a transmembrane protein which has no known function, which is constitutively cleaved into peptides during the metabolic functions of the cell (Haass et al., 1992). However, in the case of overproduction (or impaired clearance), $A \beta$ aggregates into extracellular oligomers, fibrils and eventually, plaques (Masters et al., 1985). Whereas, tau is an intracellular microtubule binding protein which, when hyper-phosphorylated, results in the disassembly of microtubules and thus leads to the impediment axonal transport and compromises neuronal and synaptic functions (Iqbal et al., 2005). There are now several studies linking obesity and other metabolic disorders with an increased risk of AD. In addition, the inflammation and the pathogens interaction hypothesis (i.e. microbial infections are causing the tau tangles and build-up of amyloid proteins, resulting in the ensuing cell death) were also risk factors of $A D$ development.

The 'gut microbiota' can be defined as all the species within the ecosystem and are considered the largest reservoir of microbes in the human body, containing about $10^{14}$ microbes. Over $99 \%$ of microbiota in the Gl tract are anaerobic bacteria, with archaebacterial, protozoa, fungi, and other microorganisms making up the remainder (Hill et al., 2014). These GI microbiota play many important roles in physiological homeostasis and metabolism, conferring many health benefits on the host organism, including pathogen displacement, immune system development, barrier fortification, vitamin production and nutrient absorption, and is often referred to as the 'forgotten organ' as a result of what it is (O'Hara and Shanahan, 2006). Consequently, there is a great deal of impetus for the comprehensive 
understanding of the complete pathological function, genetic information and functional diversity of the gut microbiome that may lead to clinical $A D$ and the discovery of variable risk factors (Clemente et al., 2012).

In this review, we examine the roles of the gut microbiota in the maintenance of health, inflammation process; and how it is implicated in acquired metabolic diseases and agingrelated morbidity; highlighting the dementia, particularly in $A D$ regulation. Finally, we discuss the potential modification to providing clinical benefit of the gut microbiome and other methods for $A D$ avoidance.

\section{BRAIN-GUT AXIS}

Bidirectional communications between the gut tract and the central nervous system (CNS) - the braingut axis-occur in both sickness and health. Recently, a role of the enteric microbiota which count as both commensal and pathogenic organisms (such as Bifidobacterium and Escherichia), in the brain-gut axis interactions was essentially identified (Grenham et al., 2011). The gut microbiota assists a number of everyday functions in the brain, including the regulation of the hypothalamic-pituitary-adrenal (HPA) axis activation state. The release of cortisol as a result of HPA axis activation can in turn govern the activation state of brain microglia, and effect cytokine release as well as attracting of monocytes from the periphery to the brain. They also can rule actions in the periphery and central nervous system by various means of communication including vagal nerve and adrenergic nerve activation as well as producing several molecular candidates such as neurotransmitters, neuropeptides, endocrine hormones and immunomodulators. Host stress hormones such as noradrenaline, which might affect bacterial activities or signalling between bacteria, may change the microbial diversity and actions of the gut microbiota. However, these bacteria are capable of synthesizing and releasing many neurotransmitters and neuromodulators themselves, or evoke the synthesis and release of neuropeptides from enteroendocrine cells. For example: Lactobacillus and Bifidobacterium species can produce shortchain fatty acids; Escherichia, Bacillus and Saccharomyces spp. can produce norepinephrine; spore-forming microbes can produce 5-HT; Bacillus can produce dopamine, and Lactobacillus can produce acetylcholine (Table 1) (Grenham et al., 2011; Wall et al., 2014; Potgieter et al., 2015; Yano et al., 2015).

Dysfunction in the brain-gut microbiota axis was investigated in irritable bowel syndrome, inflammatory bowel disease, depression, and anxiety, as well as neurodevelopmental disorders such as autism, Parkinson's disease (PD), and AD (Bonaz and Bernstein, 2013; Dinan and Cryan, 2013; Hsiao et al., 2013; Borre et al., 2014b). For example, the recent experimental study of Holmqvist et al demonstrated that $\alpha$-synuclein, the presynaptic neuronal protein which is abundantly expressed in the brain, was presented in PD brain lysate and distinct recombinant $\alpha$-synuclein forms were transported via the vagal nerve and reached the dorsal motor nucleus of the vagus in the brainstem in a time-dependent manner after injection into the intestinal wall. The authors indicated that different $\alpha$-synuclein forms can spread from the gut to the brain, and that microtubule-associated transport is joined in the translocation of aggregated $\alpha$-synuclein in neurons (Holmqvist et al., 2014). In addition, Scheperjans et al studied the microbiota composition in PD patients and healthy controls. The results suggested a significant decrease of Prevotellaceae in PD patients and the subjects with a lower abundance of Prevotellaceae ( $<6.5 \%$ in relative abundance) showed a higher risk of PD. In another study, the abundance of Enterobacteriaceae was positively correlated with the severity of PD regarding gait difficulty and postural instability (Scheperjans et al., 2015).

\section{THE ROLE OF GUT MICROBIOTA IN AD VIA THE INFLAMMATION REGULATION}

Inflammation is the body's response to infections and tissue injury and the inflammatory response is orchestrated by the cells of the immune system; both from the "adaptive" branch (including $\mathrm{T}$ - and B-cells with the capacity to induce longterm memory of encountered pathogens, "immunisation") and the "innate" branch (including monocytes, macrophages, dendritic cells, and mast cells, that are targeted against common pathogen antigens). Inflammation was first implicated in AD pathology and development in the 1990s, with the neuropathological finding of activated inflammatory cells (microglia and astrocytes) and inflammatory proteins (e.g. cytokines and complement), surrounding the amyloid plaques and the neurofibrillary tangles (Aisen and Davis, 1994). In addition to the epidemiological findings, patients suffering from arthritis and other patient groups with a high intake of non-steroidal anti-inflammatory drugs (NSAID) were observed to have had a lower proportion of individuals affected with AD. Many of the earliest results were at first dismissed as inaccurate given the perception of the brain as an "immune privileged" organ, i.e. an organ that does not elicit inflammation in response to antigens or damage. However, abundant literature can now be found in relation to the presence of acute phase proteins in $A \beta$ plaques, activated microglial cells that stain for inflammatory cytokines, and components of the complement system in brain tissue of $A D$ patients. Identifying inflammation-associated risk factors for AD could provide clues to the aetiology of AD and lead to novel strategies for combating the disease (Akiyama et al., 2000; Cacquevel et al., 2004). Since the initial discovery of a potential inflammatory ingredient to the AD cocktail, studies have diversified to look at a multitude of inflammation-associated risk factors for cognitive function, cognitive decline, $A D$, dementia and progression in dementia; including circulating inflammatory markers (Engelborghs et al., 1999; Yaffe et al., 2003; Tan et al., 2007; Zuliani et al., 2007), genetic sequence variation in immune-related genes (Arosio et al., 
Table 1. The gut bacteria and their metabolites on the nervous system

\begin{tabular}{|c|c|c|c|}
\hline Gut microbiota & $\begin{array}{l}\text { Metabolites } \\
\text { product }\end{array}$ & Effects on the nervous system function & References \\
\hline Lactobacillus, Bifidobacterium & GABA & $\begin{array}{l}\text { Inhibitory neurotransmitter, metabolic disorders } \\
\text { can lead to anxiety and depression }\end{array}$ & (Barrett et al., 2012) \\
\hline $\begin{array}{l}\text { Streptococcus, Escherichia, } \\
\text { enterococci, Enterococcus, } \\
\text { Lactococcus, Lactobacillus }\end{array}$ & Serotonin & Neurotransmitters, regulate emotions & $\begin{array}{l}\text { (Shishov et al., } \\
\text { 2009; Özogul, } \\
\text { 2011) }\end{array}$ \\
\hline Bacillus & Norepinephrine & $\begin{array}{l}\text { Neurotransmitters involved in motor, cognitive, } \\
\text { memory, emotion and other central nervous } \\
\text { and endocrine control }\end{array}$ & $\begin{array}{l}\text { (Tsavkelova et al., } \\
\text { 2000; Shishov } \\
\text { et al., 2009) }\end{array}$ \\
\hline Lactobacillus, Bacillus & Acetylcholine & $\begin{array}{l}\text { Acting on neurotransmitters in the central and } \\
\text { peripheral nervous systems, and cognitive } \\
\text { function, particularly closely related to } \\
\text { learning and memory }\end{array}$ & $\begin{array}{l}\text { (Marquardt and } \\
\text { Spitznagel 1959; } \\
\text { Kawashima et al., } \\
\text { 2007) }\end{array}$ \\
\hline $\begin{array}{l}\text { Lactobacillus, Lactococcus, } \\
\text { Streptococcus, Enterococcus }\end{array}$ & Histamine & $\begin{array}{l}\text { Regulating neurotransmitter; sleep and } \\
\text { cognitive function related }\end{array}$ & $\begin{array}{l}\text { (Landete et al. } \\
\text { 2008; Thomas } \\
\text { et al., 2012) }\end{array}$ \\
\hline Clostridium, C. sporogenes & $\begin{array}{l}\text { Indole-3- } \\
\text { propionic } \\
\text { acid (IPA) }\end{array}$ & Antioxidants, protect neurons & $\begin{array}{l}\text { (Jellet et al., 1980; } \\
\text { Bendheim et al., } \\
\text { 2002) }\end{array}$ \\
\hline $\begin{array}{l}\text { Bacteroides, Bifidobacterium, } \\
\text { Propionibacterium, Eubacterium, } \\
\text { Lactobacillus, Clostridium, } \\
\text { Roseburia, Prevotella }\end{array}$ & $\begin{array}{l}\text { Short-chain } \\
\text { fatty acids } \\
\text { (SCFA) }\end{array}$ & $\begin{array}{l}\text { Carbohydrates (starch, cellulose, etc.), the main } \\
\text { products of fermentation, to provide energy for } \\
\text { the host, regulate endothelial cell function, } \\
\text { promote the synthesis and secretion of } \\
\text { neurotransmitters and hormones, reduce } \\
\text { inflammation }\end{array}$ & $\begin{array}{l}\text { (Russell et al., } \\
\text { 2013) }\end{array}$ \\
\hline Blue-green algae (Cyanobacteria) & BMAA & $\begin{array}{l}\text { Neurotoxicity, neuronal damage, and misfolded } \\
\text { proteins related }\end{array}$ & $\begin{array}{l}\text { (Bradley and Mash, } \\
\text { 2009) }\end{array}$ \\
\hline Gram-negative bacteria & Endotoxin & $\begin{array}{l}\text { Induced inflammation, release large amounts of } \\
\text { inflammatory cytokines (TNF- } \alpha \text {, IL- } 6 \text { and IL-8, } \\
\text { etc.), obesity, IR, diabetes and is closely } \\
\text { related to the occurrence of AD }\end{array}$ & $\begin{array}{l}\text { (Levi et al., 2003; } \\
\text { Wang and Quinn, } \\
\text { 2010) }\end{array}$ \\
\hline $\begin{array}{l}\text { Escherichia, Bacillus, Lactococcus, } \\
\text { Lactobacillus, Streptococcus }\end{array}$ & Dopamine & $\begin{array}{l}\text { System activity, Parkinson's disease, AD, and } \\
\text { depression-related }\end{array}$ & $\begin{array}{l}\text { (Tsavkelova et al., } \\
\text { 2000; Shishov } \\
\text { et al., } \\
\text { 2009; Özogul, } \\
\text { 2011) }\end{array}$ \\
\hline $\begin{array}{l}\text { Spore-forming microbes, Candida, } \\
\text { Streptococcus, Enterococcus spp. }\end{array}$ & $\begin{array}{r}\text { Promote } 5-\mathrm{HT} \\
\text { biosynthesis }\end{array}$ & Increase the motility of the gut & (Yano et al., 2015) \\
\hline
\end{tabular}

NOTE: GABA: gamma-aminobutyric acid; BMAA: beta-N- methylamino -L- alanine; 5-HT: 5-hydroxytryptamine; AD: Alzheimer's disease; IR: insulin resistance.

2004; Flex et al., 2004), and proxies of inflammatory load (Gatz et al., 2006).

Microbiota affect the development of the gut associated lymphoid system (GALT). The intestines contains $70 \%$ of the body's circulating lymphocytes, many of which are found within the epithelium (Collins et al., 2012). In the lamina propria there are several lines of immune cells, key to the host response to microbiota, such as macrophages, dendritic cells and myofibroblasts (Otte et al., 2003; Bilsborough and Viney, 2004). Gut lymphoid tissue, and surface and circulating immunoglobulin concentrations show a substantial rise in observation of bacterial addition to the gut
(Macpherson and Harris, 2004). In the early stages of the human life cycle, pioneering species in the gut interact through surface cell receptors on the immune cells of the gut, such as caspase-recruitment-domain protein (CARD), and toll-like receptors (TLRs), to promote the expression of host genes that generate an intraluminal and mucosal environment that further favors their colonization (Silva et al., 1987; Hooper et al., 2001). In addition to the TLRs there is another family of membrane-bound receptors for detection of proteins called NOD-like receptors (NLRs). NRLs are located in the cytoplasm and are involved in the detection of bacterial pathogen-associated molecular patterns (PAMPs) 
that enter the mammalian cell. NRLs are especially important in tissues where TLRs are expressed at low levels (Philpott et al., 2001). In addition to intestinal epithelial cells, the epithelium includes specialized cells such as goblet cells, which secrete the protective mucus layer, limiting the contact between bacteria and epithelial cells, and Paneth cells, which reside in the crypts of the small intestine and secrete bactericidal peptides as well as the predominant class of immunoglobulin $\lg \mathrm{A}$ was also found in intestinal secretions (Cash et al., 2006). These mucosal immune responses are lessened when exposed to heat-treated bacteria in comparison to live organisms, suggesting that such mechanisms involve the metabolic products of bacterial activity as well as bacterial cell-receptor mediated sensing (Macpherson and Uhr, 2004). It should be noted that it is not only gram-negatives and lipopolysaccharides (LPS) that can induce inflammation; other cell components and metabolites can be involved, and there are also several gram-positive pathogenic (such as Enterococcus, which is often found as a contaminant in foods) and opportunistic pathogenic bacteria (such as Bifidobacterium) that can induce inflammation (Gonzalez-Navajas et al., 2008). An endeavour searching for the connection between gut microbiota and systemic inflammation showed that approximately $9 \%$ of the total variability of the microbiota was correlated to the pro-inflammatory cytokines IL-8 and IL-6 (Biagi et al., 2010). All taxa that showed a slightly positive association with either IL- 6 or IL-8 belonged to the phylum Proteobacteria (Biagi et al., 2010). It is possible that low-grade systemic inflammation constitutes a common denominator in neurodegenerative and vascular diseases, possibly via detrimental effects on the vasculature and leading to a dysfunctional brain-blood barrier and inflammatory stimuli of the brain. Elevated peripheral inflammation could also affect brain inflammation by the "priming" of neurones, i.e. making them more prone to a pro-inflammatory response in the presence of tissue damage (Holmes et al., 2009). In addition, chronic inflammation during foetal and childhood development could negatively affect brain development and lower the "cognitive reserve" (Borenstein et al., 2006).

The researchers noted that the affected $A D$ brains are largely inflamed, glial cells rushing to the brain regions that become ill and trying to clean up waste products from cells and plaque, but once up to this area, they in fact are urged to liberate more $A \beta$ harmful, precipitate in the formation of plaque, which attracts more accurate glial cells, and so on. According to Balin et al and other studies, amyloid proteins play a part in the disease, but only in response to the initial inflammation caused by the microbial infection, that is attacking the brain (Balin and Hudson, 2014). Recent study showed that $A \beta$ may play a protective role in innate immunity and infectious or sterile inflammatory stimuli may drive amyloidosis and that $A \beta$ oligomerization, a behavior traditionally viewed as intrinsically pathological, may be necessary for the antimicrobial activities of the peptide, which mean that $A \beta$ serves to protect the brain from invading microbes (Kumar et al., 2016). In vitro study of Chlamydia pneumoniae showed that the infection of monocytes could stimulate innate and adaptive immune responses relevant to those in AD (Balin and Hudson, 2014; Lim et al., 2014; Little et al., 2014). Hoban et al, elucidated the mechanisms of the microbial influence by investigating changes in the homeostatic regulation of neuronal transcription of germ-free mice within the prefrontal cortex, and showed that the microbiome is necessary for appropriate and dynamic regulation of myelin-related genes (the formation of fatty sheathing that insulates nerve fibres), with clear implications for cortical myelination at an ultrastructural level (Hoban et al., 2016). Experiments by Lee et al also showed that the germfree mice were protected from causing the case experimentally, similar to multiple sclerosis, characterized by the demise of myelin, which encases nerve fibers (Lee et al., 2011). There is also the possibility that these hypothetical pathways are tangled and that e.g. $A \beta$ deposits in the cerebrovascular wall will elicit a peripheral inflammatory response that will in turn enhance brain inflammation (Fig. 1).

\section{PUTATIVE ROLE OF MICROBES' PRODUCTS}

The dysfunction of the gut epithelial barrier resulting from dysregulation of the brain-gut -microbiota axis could promote invasion of neuroactive substances, including neurotropic viruses, unconventional pathogens with prion-like properties, or slow neurotoxins (Hawkes et al., 2007). Some microbes can remain latent in the body with the potential for reactivation, the effects of which might happen years after early infection; and that people can be infected but not necessarily affected, such that 'controls', even if infected, but with symptoms (Itzhaki, 2014). It is remarkable that human microorganisms that produce amyloids such as CsgA, A 442 , and other peptides that accrue in AD brains (Hill and Lukiw, 2015). For example, amyloids are related to fungal surfacestructures and the new statement of amyloidogenic fungal proteins and diffuse mycoses in the blood of $A D$ patients suggest that chronic fungal infection associates with high risk of AD (Hill et al., 2014). Moreover, Escherichia coli produce extracellular amyloids known as curli fibers, composed of the major structural sub-unit CsgA, are a common secretory component that facilitate surface adhesion, biofilm development and protection against host defences (Schwartz and Boles, 2013). A number of bacterial amyloid systems include Pseudomonas, Streptomyces, Staphylococcus, Bacillus, and others, propose that functional amyloids are an extensive phenomenon used by a wide diversity of microbiomes (Schwartz and Boles, 2013; Hill et al., 2014). Furthermore, bacterial enzymes may also produce neurotoxic metabolites such as D-lactic acid and ammonia (Galland, 2014). The direct neural communication between the gut and the brain occurs via the vagal 


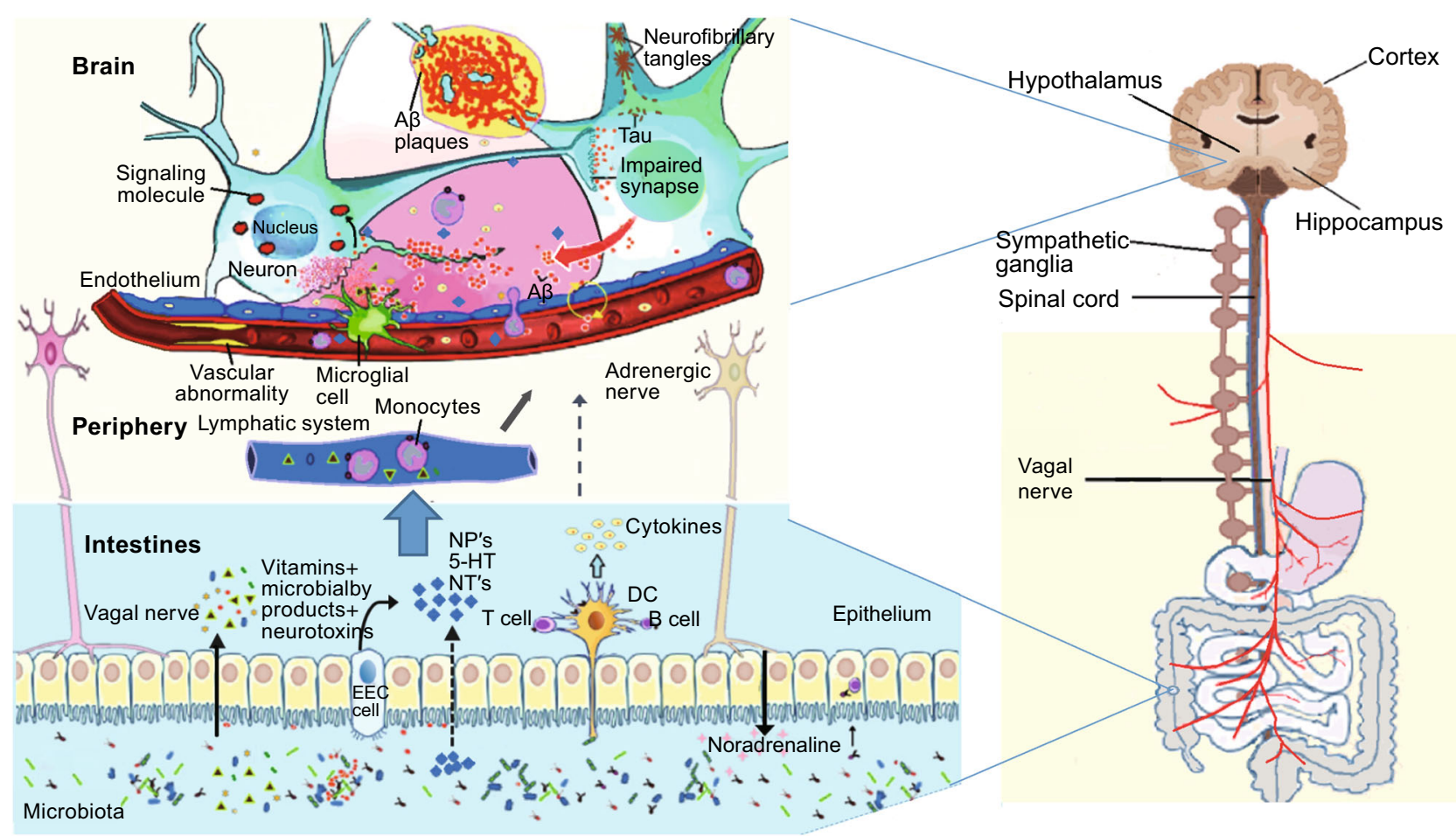

Figure 1. Schematic of some key players in the pathogenesis of AD. The gut microbiota regulation of neuro-inflammation and the hypothalamic-pituitary-adrenal (HPA) axis activity and may lead to AD. The bacterial products that gain access to the brain through the bloodstream and the area postrema, via cytokine release from mucosal immune cells, through the release of gut hormones such as 5-HT from EEC cells, or via afferent neural pathways, including the vagal nerve. NP: Neuropeptide; NT: Neurotransmitter; 5-HT: 5-hydroxytryptamine; DC: Dendritic cell; EEC: Enteroendocrine cell; A $\beta$ : amyloid beta protein; AD: Alzheimer's disease.

nerve, as bacteria can stimulate afferent neurons of the enteric nervous system (ENS) (Forsythe et al., 2014). Vagal signals from the gut could also induce an anti-inflammatory reaction to protect the body from the infections caused by pathogens in a nicotinic acetylcholine receptor $\alpha 7$ sub-unit dependent manner (Grenham et al., 2011; Borre et al., 2014a; Forsythe et al., 2014; Mulak and Bonaz, 2015). Additionally, other human gut-resident Cyanobacteria-generated neurotoxins including $\beta$ - $N$-methylamino-l-alanine (BMAA), saxitoxin, and anatoxin- $\alpha$ may further contribute to neurological diseases as amyotrophic-lateral sclerosis (ALS), the Parkinson-dementia complex of Guam, and AD especially over the course of aging (Brenner, 2013; Lakhan et al., 2013; Tran and Greenwood-Van Meerveld, 2013). Parodi et al demonstrated that rosacea patients have a significantly higher small intestinal bacterial overgrowth (SIBO) prevalence than controls, The effectiveness of SIBO eradication in rosacea may recommend that these bacteria play a role in the pathogenesis of rosacea lesions(Parodi et al., 2008). Moreover, patients who have rosacea are at increased risk of developing dementia, particularly AD (Nursing-Standard, 2016).

\section{GUT MICROBIOTA AND METABOLIC DISEASES}

High-fat diets and sedentary lifestyles have become major concerns throughout the world. The morbid conditions related to obesity such as abdominal obesity, insulin resistance and glucose intolerance, hypertension and dyslipidemia are together called the metabolic syndrome. Obesity and its coassociated morbidities, namely cardiovascular disease (CVD), type-2 diabetes mellitus (T2DM), fatty liver disease and hypertension are a great economic burden in affected countries. Of note, accumulating evidence suggests a mechanistic relation between the cholesterol metabolism in the brain and the formation of $A B$ plaques in $A D$ development (Martins et al., 2006). High blood sugar and body fat can place you at a higher risk for $A D$ and blood restriction. Metabolomics study by Dumas et al suggested that gut microbiota may also play an active role in the development of complex metabolic abnormalities, such as susceptibility to insulin resistance and fatty liver disease (Dumas et al., 2006). Subsequent analysis of germ-free versus conventional mice on high-fat diet revealed that both insulin sensitivity and cholesterol metabolism are metabolic targets 
influenced by the gut microbiota (Rabot et al., 2010). Complementary clinical studies further demonstrated that raised circulating levels of the gut microbiota metabolite within subjects predicted increased cardiovascular danger independent of traditional cardiovascular risk factors (Wang et al., 2011). Increasingly, the role of CVD is also being recognized as an important etiologic hallmark of $A D$. Indeed, many studies were summarized findings on CVD and risk factors in the aetiology of $A D$ and showed the importance of vascular pathology in AD (Jagust, 2001; de la Torre, 2004; de Bruijn and Ikram, 2014). Consequently, there is an increasing number of proofs suggesting that gut microbiota, through a variety of processes, can influence physiological processes important for the development of CVD (Hazen and Smith, 2012).

\section{OBESITY INCREASES THE RISK OF COGNITIVE IMPAIRMENT OR MENTAL DECLINE}

It is generally believed that gut microbiota control obesity, the major cause of T2DM, which has recently been linked with AD development (Pasinetti et al., 2011). Recent studies have also found the role of gut microbiota in the control of brain function directly by tryptophan metabolism, production of microbial metabolites, microbial neurotransmitters and bacterial cell wall sugars and bile acids (Swann et al., 2011; Collins et al., 2012; Tremaroli and Backhed, 2012). Tremaroli et al found conclusive evidence that gut microbiota could influence the activity of lipoprotein lipase (LPL) -the key enzyme involved in the release of fatty acids from triglyceride-rich lipoproteins in muscle, heart, and fat- by affecting the expression of fastinginduced adipocyte factor protein (FIAF) - key inhibitor of LPL activity and plays an important role in preventing obesity- that was over expressed in the germfree mice and reduce storage of triglycerides in the adipose tissue (Tremaroli and Backhed, 2012). Upregulation of adipocyte LPL activity leads to increase cellular uptake of fatty acids and adipocyte triglyceride accumulation. Consequently, suppression of intestinal FIAF by microbes promotes adiposity through upregulation of LPL activity in adipocytes and increased hepatic lipogenesis were found to enhance the accumulation of calories harvested from the diet into fat then storage in the liver, which is the main cause of insulin resistance in obesity (Fig. 2). Moreover, specific bacterial taxa of the gut microbiota are involved in nutrient uptake and energy homeostasis and may lead to low grade inflammation induced by LPS, causing activation of the innate immune response. This low grade inflammation is connected to low, but constant levels of LPS in the circulation and to increased levels of adiposity and insulin resistance (obesity and T2DM) (DiBaise et al., 2008). Additionally, previous literature demonstrated that ileal inflammation, decreased LPS activity, and increased innate immune system activation was observed in rats susceptible to weight gain as compared to the obesity resistant rats (de La Serre et al., 2010).

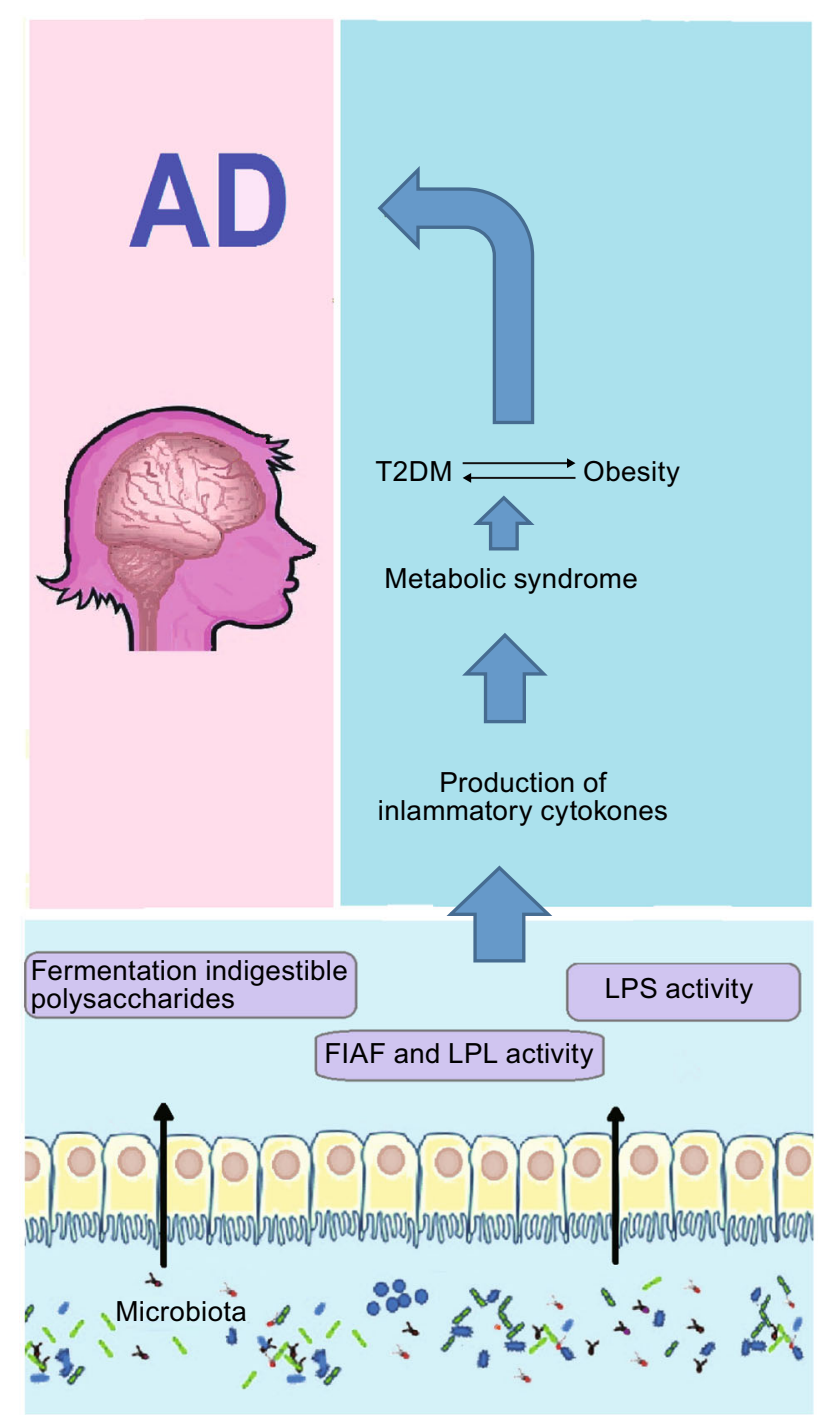

Figure 2. The links between gut microbiota and metabolic diseases, as obesity and further development of T2DM with AD. FIAF: fasting-induced adipocyte factor; LPS: lipopolysaccharide; LPL: lipoprotein lipase; T2DM: type 2 diabetes mellitus; AD: Alzheimer's disease.

\section{TYPE-3 DIABETES}

New evidence has come to light concerning the different expressions of diabetes, as well as its connection to other diseases. It used to be supposed that there were two types of diabetes: type-1 and type-2. However, the idea that $A D$ might be type-3 diabetes was proposed ten years ago (Martins et al., 2006). Some studies suggested that AD progresses because of the brain developing resistance to insulin, which in turn prevents proper lipid uptake. Over time, these lipids build up in the brain rather than properly absorb, which results in increased stress and inflammation, as well as the symptoms usually related with dementia (de la Monte, 2014; Rani et al., 2016). Given the evidence provided by 
animal models of the strong relationship between T2DM and AD. When the authors blocked the path of insulin to rats' brains, their neurons deteriorated, they became physically confused and their brains showed all the signs of AD. Furthermore, the study provided proof that T2DM and $A D$ aggravate each other and suggested several potential mechanisms underlying the two disorders, such as, $A \beta$ clearance by insulin degradation enzyme (IDE), glucose metabolism, O-GlcNAcylation, $A \beta$ aggregation by advanced glycation end products (AGEs), oxidative stress, circulating cortisol, and cerebral vascular insufficiency, as well as inflammation, and aging. In fact, people with diabetes have double the risk of developing AD. This does not mean that everyone who has diabetes will eventually develop $A D$, or that all people with $A D$ have diabetes. It is important to report that there is an important link between diabetes and $A D$, and it is therefore common that pathophysiology probably constitutes a major underpinning of late-onset sporadic $A D$, and a novel therapeutic approach targeting this pathological process could contribute to the development of a more efficient and effective treatment for AD (Park, 2011; de la Monte, 2014).

\section{AGING}

Alzheimer's cases show a dramatic increase with age, affecting about $1 \%$ of the population aged between $65-69$ years up to $30-40 \%$ in the oldest individuals (Gatz et al., 2006). Overall occurrence in the population above 65 years of age is estimated to $6-8 \%$ and is expected to increase significantly worldwide due to changing demographic profiles with an ever-increasing proportion of elderly (Ferri et al., 2005). Indeed, as adulthood approaches, the gut microbiota stabilizes, becomes more diverse, and can resist detrimental environmental elements such as antibiotics and stress by restoring its diverse and stable 'normal' core microbiota (Palmer et al., 2007; Rajilic-Stojanovic et al., 2011). However, as we age, the diversity and stability of our microbiota will decline (Biagi et al., 2010), moreover there is an associated increase in number, size and activation of microglia that can lead to an increased inflammatory tone named 'inflammaging' (Franceschi, 2007; von Bernhardi et al., 2015). There is high heterogeneity of microglia in several neurodegenerative diseases, including $A D$ and those phenotypes share common characteristics with aging (Bachstetter et al., 2015). In normal aging, close crosstalk with astrocytes, neurons and other brain cells serve crucial functions as the scavenger system of the CNS, providing beneficial functions such as tissue repair in the CNS. However, chronic, dysregulated activation of microglia can lead to elevated inflammatory tone ultimately resulting in the malfunction or damage of brain cells. The role of the microbiota in addition to what drives this dysregulation has yet to be fully understood.

\section{AD MICE AND GUT MICROBIOTA}

A recent experimental study conducted by Harach et al observed marked differences of the gut microbiota composition between aged $A D$ mice and healthy WT mice and strongly advocated that a distinct microbial constitution in $A D$ mice may play a role in the development of cerebral $A \beta$ amyloidosis (Harach et al., 2015). In this study, the authors demonstrated that the abundance of the two major phyla (Firmicutes andBacteroidetes) in the fecal microbiota is dramatically altered by host genetics. At genus level, Allobaculum and Akkermansia were decreased in transgenic CONVR-APPPS1 mice and unclassified genera of Rikenellaceae and S24-7 were increased. Reduced levels of Akkermansia have been associated with obesity and type 2 diabetes in mice (Everard et al., 2013), and the prebioticinduced restoration of Akkermansia in the gut resulted in a lower fat-mass gain and decreased systemic inflammation (two discussed risk factors in the development of $A D$ pathology). Furthermore, the relative abundance of several bacterial genera was correlated with the amount of soluble Aß42 in the brain (Harach et al., 2015).

\section{DELAY THE PROCESS OF NEURODEGENERATION}

\section{Probiotics and prebiotics}

The increased understanding of the impact of the gut microbiota on human health resulted in attempts to manipulate its composition by the use of probiotics and prebiotics, from both prophylactic and therapeutic perspectives. Probiotics are defined as live microbial organisms that, when consumed in adequate quantities, confer health benefits to the host (Berg, 1998). Prebiotics are chemical substances, usually oligosaccharides, acting as substrates specifically for the host's autochthonous probiotic bacteria, and thus promoting their growth. Prebiotics are selected as being non-digestible by the host and nonmetabolizable by non-probiotic gut bacteria, but stimulating for bifidobacteria and lactobacilli (Gibson et al., 2004; Hamilton-Miller, 2004). A food is considered synbiotic when it contains a prebiotic and a probiotic ingredient. The species Lactobacillus, Bifidobacterium and Streptococcus are the most commonly studied to date because they are common and are 'natural' members of the intestinal microbiome (Gordin and Gorbach, 1992; Berg, 1998). Moreover, these bacteria do not necessarily need to be alive, as products of the bacteria, such as cell walls and bacterial DNA, can modulate the profile of the gut microbiota and immune responses (Agostoni et al., 2004; Thibault et al., 2004). Their main beneficial effects are to function as the first barrier to pathogenic organisms by adherence, to produce substances that have antimicrobial effects, and to stimulate the immune processes in the host (Floch, 2005; Chermesh and Eliakim, 2006). Furthermore, certain strains of lactic acid bacteria (LAB) produce 
the complex vitamin cobalamin (or vitamin B12) which directly associated with $A D$, based on many of the studies which showed that vitamin B12 levels are lower in $A D$ individuals compared with healthy subjects (LeBlanc et al., 2013; Chen et al., 2015). Additionally, fermented milks with high levels of B-group vitamins (such as folate and riboflavin) can be produced by LAB-promoted and possibly $\mathrm{Bi}$ fidobacteria-promoted biosynthesis (LeBlanc et al., 2013). As the pathogenesis of different diseases is diverse, the mechanisms by which bacteria effect disease processes are unique. All the same, probiotic development shows great capacity for rebuilding microbiotas and restoring health, especially for some individuals. Therefore, the practical application portability of species beneficial in one illness will not necessarily hold for another. As for the prebiotics, inuline supplementation was reported to be able to increase the viable count of bifidobacteria in constipated elderly, while the frequency of the detection of enterobacteria decreased with the treatment. The ingestion of inuline improved constipation in 9 out of 10 subjects (Kleessen et al., 1997). It was reported that fructo-oligosaccharide ingestion (Guigoz et al., 2002; Bouhnik et al., 2007), as well as the supplementation of a galacto-oligosaccharide mixtures are able to significantly increase the numbers of bifidobacteria at the expense of less beneficial groups (Vulevic et al., 2008).

\section{NSAIDs}

Several epidemiological studies suggested that NSAIDs may delay the onset of $A D$ for up to five or more years, and are even able to prevent the onset of $A D$ in patients with mild cognitive impairment $(\mathrm{MCl})$ or in healthy elderly subjects at risk of developing AD (Imbimbo et al., 2010). Thus, it could be hypothesized that the chronic use of NSAIDs may be beneficial only in the very early stages of the AD process in coincidence of initial $A \beta$ deposition, microglia activation and consequent release of pro-inflammatory mediators. When the $A \beta$ deposition process is already started, NSAIDs are no longer effective and may even be detrimental because of their inhibitory activity on chronically activated microglia that on long-term may mediate $A \beta$ clearance (Imbimbo et al., 2010). In conclusion, these studies indicate that there is a dose-response relationship between NSAID use and the relative risk of $A D$, with longer periods of use related to reduce relative risks of $A D$. Based on these studies, the relative risk of $A D$ appears to be $25-50 \%$ lower in groups of individuals with long-term (2 years or more) NSAID use (in t' Veld et al., 2001). The reduction in risk also appears to be restricted to $A D$; no protective effect against vascular dementia was noted. The hypothesis is that the inflammatory response to the accumulating $A \beta$ and tau deposits worsens the pathological process and that NSAIDs may alleviate the process by inhibiting the inflammatory response and/or inhibiting glutamate toxicity (Casper et al., 2000; Imbimbo et al., 2010).

\section{Grape seed}

Grape seed polyphenol extract (GSPE) was widely considered a dietary supplement with widespread health benefits. Many studies recently demonstrated the potential efficacy of GSPE in protecting against neuropathology and cognitive impairment in animal models of $A D$ and tau-mediated neurodegenerative disorder (Wang et al., 2008; Santa-Maria et al., 2012). The growing body of experimental, preclinical, and clinical evidence supporting GSPE exerting beneficial biological activities in multiple medical conditions, has led to increased interest in its bioavailability, metabolism, and distribution of the primary GSPE phenolic constituents, including gallic acid, epicatechin, proanthocyanidin dimers, and larger oligomers. Interestingly, evidence suggests that intestinal microbiota significantly contribute to GSPE metabolism/absorption, as catechin and epicatechin, major components of GSPE, are both metabolized by colonic microbiota fermentation (Aura et al., 2002; Cueva et al., 2013). Wang et al demonstrated that intestinal microbiota may contribute to the protective activities of GSPE in neurodegenerative disorders, and in other diseases, by converting proanthocyanidin components from GSPE to phenolic acid metabolites capable of accumulating in target tissues, such as the brain, and of exerting disease-modifying activates (Wang et al., 2015). Table 2 summarize the methods described above.

\section{Critical challenges}

During the last three decades, Alzheimer's research has not only made remarkable progress in understanding the disease but also has recruited some of the best scientists in the world. The prospect of delaying or preventing the onset of symptoms is feasible and within our grasp. However, this mission must surmount a number of barriers, which contain inadequate funding of research, high cost of clinical studies, lack of suitable infrastructure, better models, antiquated administrative structure of discovery programs, and arcane decision-making systems for selecting and funding innovative ideas. Recently, the only way to know for certain that someone has $A D$ is to examine an autopsy of their brains tissue after death. The crucial challenge for the AD researches is how to understand the process of neurodegenerative disorders throughout the patient's lifetime. Additionally, the lack of efficient cultivation techniques stems from many factors that largely remain unknown (Lopez et al., 2015). Hence, molecular ecology and metagenomics have significantly increased our knowledge of the genetic diversity and have led to interesting hypotheses (Hugenholtz and Tyson, 2008). The advanced techniques have also revealed how far 
Table 2. Some methods that using to delay the process of neurodegeneration

\begin{tabular}{|c|c|c|c|}
\hline Products & Description & Components & Foods contain them \\
\hline Probiotic & $\begin{array}{l}\text { Live microorganisms confer a health benefit } \\
\text { and boost the host immunity }\end{array}$ & $\begin{array}{l}\text { - Lactobacillus acidophilus } \\
\text { - Lactobacillus casei } \\
\text { - Lactobacillus reuteri } \\
\text { - Lactobacillus plantarum } \\
\text { - Lactobacillus rhamnosus } \\
\text { - Bifidobacterium animalis } \\
\text { - Bifidobacterium infantis } \\
\text { - Bifidobacterium lactis } \\
\text { - Bifidobacterium longum }\end{array}$ & $\begin{array}{l}\text { Yogurt, Soy yogurt } \\
\text { fermented dairy products } \\
\text { Kombucha }^{a}, \text { Kimchi }^{\mathrm{b}} \\
\text { Miso }^{\mathrm{c}}, \text { Sauerkraut }^{\mathrm{d}}\end{array}$ \\
\hline Prebiotic & $\begin{array}{l}\text { Chemical substances, nondigestible foods } \\
\text { that make their way through our digestive } \\
\text { system and help good bacteria grow and } \\
\text { flourish. Prebiotics help feed and keep } \\
\text { beneficial bacteria healthy }\end{array}$ & $\begin{array}{l}\text { Mostly come from } \\
\text { carbohydrate fibers called } \\
\text { oligosaccharides }\end{array}$ & $\begin{array}{l}\text { Bananas, Onions, Garlic, Leeks, } \\
\text { Asparagus, Whole wheat, Barley, } \\
\text { Rye, Inulin }\end{array}$ \\
\hline NSAIDs & $\begin{array}{l}\text { A drug class that groups together drugs: } \\
\text { provide analgesic (pain-killing) } \\
\text { and antipyretic (fever-reducing) effects, } \\
\text { and, in higher doses, anti- } \\
\text { inflammatory effects }\end{array}$ & $\begin{array}{l}\text { Aspirin, indomethacin, } \\
\text { ibuprofen, ketoprofen, } \\
\text { diclofenac, piroxicam, } \\
\text { celecoxib, nimesulid }\end{array}$ & $\begin{array}{l}\text { Apples, Avocados, Blueberries, } \\
\text { Broccoli, Cauliflower, Cherries, Chili } \\
\text { peppers, Cucumbers, Dates, } \\
\text { Eggplant, Figs... }\end{array}$ \\
\hline GSPE $^{f}$ & $\begin{array}{l}\text { An industrial derivative of whole grape seeds } \\
\text { used as a dietary supplement with } \\
\text { widespread health benefits }\end{array}$ & $\begin{array}{l}\text { Catechin, gallic acid, } \\
\text { epicatechin, } \\
\text { proanthocyanidin dimers, } \\
\text { larger oligomers }\end{array}$ & Grape seeds \\
\hline $\begin{array}{l}\text { Kombucha } \\
2000 \text { year } \\
\text { Kimchi-a } \\
\text { Miso is } m \\
\text { Sauerkrau } \\
\text { Inulin is a }\end{array}$ & $\begin{array}{l}\text { lightly effervescent drink that is brewed with tea } \\
\text { go. } \\
\text { ditional Korean lacto-fermented condiment ma } \\
\text { by adding an enzymatic culture to a soybean } \\
\text { cabbage that has been salted and lacto-fermen } \\
\text { tural prebiotic fiber that is found in over } 36,000\end{array}$ & $\begin{array}{l}\text { sugar and fermented into a liq } \\
\text { from cabbage. } \\
\text { over a period of weeks. } \\
\text { over worldwide. }\end{array}$ & This beverage originated in China nearly \\
\hline
\end{tabular}

we are from measuring the full extent of genetic diversity encoded by microbial life (Hugenholtz and Tyson, 2008; Pignatelli et al., 2008).

\section{SUMMARY}

Microbial colonization of the gut plays a key role in the postnatal development and maturation of the immune, endocrine and even neural systems, these processes are key factors underpinning CNS signalling. Indeed, understanding the gut microbiota is important in relation to inflammation and metabolic diseases that have a direct relation to the $A D$ pathogenesis. Moreover, comparative analysis of gut microbiota may enable further novel vision into the complex biology of $A D$, which is very important in order to take preventive measure such as early diagnosis, identification of new therapeutic targets and development of novel drugs. Thus, modulation of gut microbiota (by probiotics or other dietary intervention) or direct targeting of gut microbiota enzymes (by pharmacological inhibitors or activators) may be a growing area for pharmaceutical and functional food industries, with the goal of decreasing the widespread growth of adiposity, insulin resistance, AD, and other metabolic diseases.

\section{ACKNOWLEDGEMENTS}

BZ is supported by the National Natural Science Foundation of China (Grant No. 31270168), and Major State Basic Research Development Program (2015CB554204).

\section{ABBREVIATIONS}

$A \beta$, amyloid beta; $A D$, Alzheimer's disease; AGEs, advanced glycation end products; ALS, amyotrophic-lateral sclerosis; BMAA, $\beta-N$-methylamino-I-alanine; CARD, caspase-recruitment-domain protein; CNS,central nerve system; CVD, cardiovascular disease; ENS, enteric nervous system; FIAF, fasting-induced adipocyte factor protein; GALT; gut associated lymphoid system; GSPE, Grape seed polyphenol extract; HPA, hypothalamic-pituitary-adrenal; IDE, insulin degradation enzyme; LAB, lactic acid bacteria; LPL, lipoprotein lipase; LPS, lipopolysaccharide; $\mathrm{MCl}$, mild cognitive impairment; NLRs, NOD-like receptors; NSAIDs, non-steroidal anti-inflammatory drugs; PD, Parkinson's disease; SIBO, higher small intestinal 
bacterial overgrowth; T2DM, type-2 diabetes mellitus; TLRs, toll-like receptors

\section{CONFLICT OF INTEREST}

Rashad Alkasir, Jing Li, Xudong Li, Miao Jin, and Baoli Zhu declare that they have no conflict of interest.

This article does not contain any studies with human or animal subjects performed by the any of the authors.

\section{OPEN ACCESS}

This article is distributed under the terms of the Creative Commons Attribution 4.0 International License (http://creativecommons.org/ licenses/by/4.0/), which permits unrestricted use, distribution, and reproduction in any medium, provided you give appropriate credit to the original author(s) and the source, provide a link to the Creative Commons license, and indicate if changes were made.

\section{REFERENCES}

Agostoni C, Axelsson I, Braegger C, Goulet O, Koletzko B, Michaelsen KF, Rigo J, Shamir R, Szajewska H, Turck D et al (2004) Probiotic bacteria in dietetic products for infants: a commentary by the ESPGHAN Committee on Nutrition. J Pediatr Gastroenterol Nutr 38:365-374

Aisen PS, Davis KL (1994) Inflammatory mechanisms in Alzheimer's disease: implications for therapy. Am J Psychiatry 151:1105-1113

Akiyama H, Barger S, Barnum S, Bradt B, Bauer J, Cole GM, Cooper NR, Eikelenboom P, Emmerling M, Fiebich BL et al (2000) Inflammation and Alzheimer's disease. Neurobiol Aging 21:383-421

Arosio B, Trabattoni D, Galimberti L, Bucciarelli P, Fasano F, Calabresi C, Cazzullo CL, Vergani C, Annoni G, Clerici M (2004) Interleukin-10 and interleukin-6 gene polymorphisms as risk factors for Alzheimer's disease. Neurobiol Aging 25:1009-1015

Aura AM, O'Leary KA, Williamson G, Ojala M, Bailey M, PuupponenPimia R, Nuutila AM, Oksman-Caldentey KM, Poutanen K (2002) Quercetin derivatives are deconjugated and converted to hydroxyphenylacetic acids but not methylated by human fecal flora in vitro. J Agric Food Chem 50:1725-1730

Bachstetter AD, Van Eldik LJ, Schmitt FA, Neltner JH, Ighodaro ET, Webster SJ, Patel E, Abner EL, Kryscio RJ, Nelson PT (2015) Disease-related microglia heterogeneity in the hippocampus of Alzheimer's disease, dementia with Lewy bodies, and hippocampal sclerosis of aging. Acta Neuropathol Commun 3:015-0209

Balin BJ, Hudson AP (2014) Etiology and pathogenesis of late-onset Alzheimer's disease. Curr Allergy Asthma Rep 14:013-0417

Barrett E, Ross RP, O'Toole PW, Fitzgerald GF, Stanton C (2012) Gamma-Aminobutyric acid production by culturable bacteria from the human intestine. J Appl Microbiol 113:411-417

Bendheim PE, Poeggeler B, Neria E, Ziv V, Pappolla MA, Chain DG (2002) Development of indole-3-propionic acid (OXIGON) for Alzheimer's disease. J Mol Neurosci 19:213-217

Berg RD (1998) Probiotics, prebiotics or 'conbiotics'? Trends Microbiol 6:89-92
Biagi E, Nylund L, Candela M, Ostan R, Bucci L, Pini E, Nikkila J, Monti D, Satokari R, Franceschi C et al (2010) Through ageing, and beyond: gut microbiota and inflammatory status in seniors and centenarians. PLoS One 5:0010667

Bilsborough J, Viney JL (2004) Gastrointestinal dendritic cells play a role in immunity, tolerance, and disease. Gastroenterology 127:300-309

Bonaz BL, Bernstein CN (2013) Brain-gut interactions in inflammatory bowel disease. Gastroenterology 144:36-49

Borenstein AR, Copenhaver Cl, Mortimer JA (2006) Early-life risk factors for Alzheimer disease. Alzheimer Dis Assoc Disord 20:63-72

Borre YE, Moloney RD, Clarke G, Dinan TG, Cryan JF (2014a) The impact of microbiota on brain and behavior: mechanisms \& therapeutic potential. Adv Exp Med Biol 817:373-403

Borre YE, O'Keeffe GW, Clarke G, Stanton C, Dinan TG, Cryan JF (2014b) Microbiota and neurodevelopmental windows: implications for brain disorders. Trends Mol Med 20:509-518

Bouhnik Y, Achour L, Paineau D, Riottot M, Attar A, Bornet F (2007) Four-week short chain fructo-oligosaccharides ingestion leads to increasing fecal bifidobacteria and cholesterol excretion in healthy elderly volunteers. Nutr J 6:42-43

Bradley WG, Mash DC (2009) Beyond Guam: the cyanobacteria/ BMAA hypothesis of the cause of ALS and other neurodegenerative diseases. Amyotroph Lateral Scler 10(Suppl 2):7-20

Brenner SR (2013) Blue-green algae or cyanobacteria in the intestinal micro-flora may produce neurotoxins such as Beta-NMethylamino-I-Alanine (BMAA) which may be related to development of amyotrophic lateral sclerosis, Alzheimer's disease and Parkinson-Dementia-Complex in humans and Equine Motor Neuron Disease in Horses. Med Hypotheses 80:103

Cacquevel M, Lebeurrier N, Cheenne S, Vivien D (2004) Cytokines in neuroinflammation and Alzheimer's disease. Curr Drug Targets 5:529-534

Cash HL, Whitham CV, Behrendt CL, Hooper LV (2006) Symbiotic bacteria direct expression of an intestinal bactericidal lectin. Science 313:1126-1130

Casper D, Yaparpalvi U, Rempel N, Werner P (2000) Ibuprofen protects dopaminergic neurons against glutamate toxicity in vitro. Neurosci Lett 289:201-204

Chen H, Liu S, Ji L, Wu T, Ma F, Ji Y, Zhou Y, Zheng M, Zhang M, Huang G (2015) Associations between Alzheimer's disease and blood homocysteine, vitamin B12, and folate: a case-control study. Curr Alzheimer Res 12:88-94

Chermesh I, Eliakim R (2006) Probiotics and the gastrointestinal tract: where are we in 2005? World J Gastroenterol 12:853-857

Clemente JC, Ursell LK, Parfrey LW, Knight R (2012) The impact of the gut microbiota on human health: an integrative view. Cell 148:1258-1270

Collins SM, Surette M, Bercik P (2012) The interplay between the intestinal microbiota and the brain. Nat Rev Microbiol 10:735-742

Cueva C, Sanchez-Patan F, Monagas M, Walton GE, Gibson GR, Martin-Alvarez PJ, Bartolome B, Moreno-Arribas MV (2013) In vitro fermentation of grape seed flavan-3-ol fractions by human faecal microbiota: changes in microbial groups and phenolic metabolites. FEMS Microbiol Ecol 83:792-805

de Bruijn RFAG, Ikram MA (2014) Cardiovascular risk factors and future risk of Alzheimer's disease. BMC Medicine 12:130 
de la Monte SM (2014) Type 3 diabetes is sporadic Alzheimers disease: mini-review. Eur Neuropsychopharmacol 24:1954-1960

de La Serre CB, Ellis CL, Lee J, Hartman AL, Rutledge JC, Raybould HE (2010) Propensity to high-fat diet-induced obesity in rats is associated with changes in the gut microbiota and gut inflammation. Am J Physiol Gastrointest Liver Physiol 299:G440-G448

de la Torre JC (2004) Is Alzheimer's disease a neurodegenerative or a vascular disorder? Data, dogma, and dialectics. Lancet Neurol 3:184-190

DiBaise JK, Zhang H, Crowell MD, Krajmalnik-Brown R, Decker GA, Rittmann BE (2008) Gut microbiota and its possible relationship with obesity. Mayo Clin Proc 83:460-469

Dinan TG, Cryan JF (2013) Melancholic microbes: a link between gut microbiota and depression? Neurogastroenterol Motil 25:713-719

Dumas ME, Barton RH, Toye A, Cloarec O, Blancher C, Rothwell A, Fearnside J, Tatoud R, Blanc V, Lindon JC et al (2006) Metabolic profiling reveals a contribution of gut microbiota to fatty liver phenotype in insulin-resistant mice. Proc Natl Acad Sci USA 103:12511-12516

Engelborghs S, De Brabander M, De Cree J, D'Hooge R, Geerts H, Verhaegen H, De Deyn PP (1999) Unchanged levels of interleukins, neopterin, interferon-gamma and tumor necrosis factor-alpha in cerebrospinal fluid of patients with dementia of the Alzheimer type. Neurochem Int 34:523-530

Everard A, Belzer C, Geurts L, Ouwerkerk JP, Druart C, Bindels LB, Guiot Y, Derrien M, Muccioli GG, Delzenne NM et al (2013) Cross-talk between Akkermansia muciniphila and intestinal epithelium controls diet-induced obesity. Proc Natl Acad Sci USA 110:9066-9071

Ferri CP, Prince M, Brayne C, Brodaty H, Fratiglioni L, Ganguli M, Hall K, Hasegawa K, Hendrie H, Huang $Y$ et al (2005) Global prevalence of dementia: a Delphi consensus study. The Lancet 366:2112-2117

Flex A, Pola R, Serricchio M, Gaetani E, Proia AS, Di Giorgio A, Papaleo P, Bernabei R, Pola P (2004) Polymorphisms of the macrophage inhibitory factor and C-reactive protein genes in subjects with Alzheimer's dementia. Dement Geriatr Cogn Disord 18:261-264

Floch MH (2005) Use of diet and probiotic therapy in the irritable bowel syndrome: analysis of the literature. J Clin Gastroenterol 39:243-246

Forsythe P, Bienenstock J, Kunze WA (2014) Vagal pathways for microbiome-brain-gut axis communication. Adv Exp Med Biol 817:115-133

Franceschi C (2007) Inflammaging as a major characteristic of old people: can it be prevented or cured? Nutr Rev 65:173-176

Fratiglioni, L.R. (2001). Epidemiology of dementia. In: Handbook of Neuropsychology (Elsevier Science B.V.) 2nd 6.

Galland $L$ (2014) The gut microbiome and the brain. J Med Food 17:1261-1272

Gatz M, Mortimer JA, Fratiglioni L, Johansson B, Berg S, Reynolds CA, Pedersen NL (2006) Potentially modifiable risk factors for dementia in identical twins. Alzheimers Dement 2:110-117

Gibson GR, Probert HM, Loo JV, Rastall RA, Roberfroid MB (2004) Dietary modulation of the human colonic microbiota: updating the concept of prebiotics. Nutr Res Rev 17:259-275
Gonzalez-Navajas JM, Bellot P, Frances R, Zapater P, Munoz C, Garcia-Pagan JC, Pascual S, Perez-Mateo M, Bosch J, Such J (2008) Presence of bacterial-DNA in cirrhosis identifies a subgroup of patients with marked inflammatory response not related to endotoxin. J Hepatol 48:61-67

Gordin B, Gorbach S (1992) Probiotics for humans. In: Fuller R (ed) The scientific basis. Chapman and Hall, London, pp 223-245

Grenham S, Clarke G, Cryan JF, Dinan TG (2011) Brain-gut-microbe communication in health and disease. Front Physiol 2:345-348

Guigoz Y, Rochat F, Perruisseau-Carrier G, Rochat I, Schiffrin EJ (2002) Effects of oligosaccharide on the faecal flora and nonspecific immune system in elderly people. Nutr Res 22:13-25

Haass C, Schlossmacher MG, Hung AY, Vigo-Pelfrey C, Mellon A, Ostaszewski BL, Lieberburg I, Koo EH, Schenk D, Teplow DB et al (1992) Amyloid beta-peptide is produced by cultured cells during normal metabolism. Nature 359:322-325

Hamilton-Miller JMT (2004) Probiotics and prebiotics in the elderly. Postgrad Med J 80:447-451

Harach T, Marungruang N, Dutilleul N, Cheatham V, Mc Coy K.D, Neher JJ, Jucker M, Fåk F, Lasser T, and Bolmont T (2015) Reduction of Alzheimer's disease beta-amyloid pathology in the absence of gut microbiota. Cornell University Library, arXiv:1509. 02273.

Hawkes CH, Del Tredici K, Braak H (2007) Parkinson's disease: a dual-hit hypothesis. Neuropathol Appl Neurobiol 33:599-614

Hazen SL, Smith JD (2012) An antiatherosclerotic signaling cascade involving intestinal microbiota, microRNA-10b, and ABCA1/ ABCG1-mediated reverse cholesterol transport. Circ Res 111:948-950

Hill JM, Lukiw W (2015) Microbial-generated amyloids and Alzheimer's disease (AD). Front Aging Neurosci 7:32-36

Hill JM, Clement C, Pogue Al, Bhattacharjee S, Zhao Y, Lukiw WJ (2014) Pathogenic microbes, the microbiome, and Alzheimer's disease (AD). Front Aging Neurosci 6:127-128

Hoban AE, Stilling RM, Ryan FJ, Shanahan F, Dinan TG, Claesson MJ, Clarke G, Cryan JF (2016) Regulation of prefrontal cortex myelination by the microbiota. Transl Psychiatry 5:42

Holmes C, Cunningham C, Zotova E, Woolford J, Dean C, Kerr S, Culliford D, Perry VH (2009) Systemic inflammation and disease progression in Alzheimer disease. Neurology 73:768-774

Holmqvist S, Chutna O, Bousset L, Aldrin-Kirk P, Li W, Bjorklund T, Wang ZY, Roybon L, Melki R, Li JY (2014) Direct evidence of Parkinson pathology spread from the gastrointestinal tract to the brain in rats. Acta Neuropathol 128:805-820

Hooper LV, Wong MH, Thelin A, Hansson L, Falk PG, Gordon JI (2001) Molecular analysis of commensal host-microbial relationships in the intestine. Science 291:881-884

Hsiao EY, McBride SW, Hsien S, Sharon G, Hyde ER, McCue T, Codelli JA, Chow J, Reisman SE, Petrosino JF et al (2013) Microbiota modulate behavioral and physiological abnormalities associated with neurodevelopmental disorders. Cell 155:1451-1463

Hugenholtz P, Tyson GW (2008) Microbiology: metagenomics. Nature 455:481-483

Imbimbo BP, Solfrizzi V, Panza F (2010) Are NSAIDs useful to treat Alzheimer's disease or mild cognitive impairment? Front Aging Neurosci 21:567-574 
in t' Veld BA, Ruitenberg A, Hofman A, Launer LJ, Van Duijn CM, Stijnen T, Breteler MM, Stricker BH (2001) Nonsteroidal antiinflammatory drugs and the risk of Alzheimer's disease. New Engl J Med 345:515-521

Iqbal K, Alonso Adel C, Chen S, Chohan MO, El-Akkad E, Gong CX, Khatoon S, Li B, Liu F, Rahman A et al (2005) Tau pathology in Alzheimer disease and other tauopathies. Biochim Biophys Acta 3:2-3 Irizarry MC, Hyman BT (2001) Alzheimer's disease. In: Batchelor T, Cudkowicz ME (eds) Principles of neuroepidemiology, vol 46. Butterworth-Heinemann, Boston, pp 69-98

Itzhaki RF (2014) Herpes simplex virus type 1 and Alzheimer's disease: increasing evidence for a major role of the virus. Front Aging Neurosci 6:56-59

Jagust W (2001) Untangling vascular dementia. Lancet 358:20972098

Jellet JJ, Forrest TP, Macdonald IA, Marrie TJ, Holdeman LV (1980) Production of indole-3-propanoic acid and 3-(p-hydroxyphenyl) propanoic acid by Clostridium sporogenes: a convenient thinlayer chromatography detection system. Can J Microbiol 26:448453

Kawashima K, Misawa H, Moriwaki Y, Fujii YX, Fujii T, Horiuchi Y, Yamada T, Imanaka T, Kamekura M (2007) Ubiquitous expression of acetylcholine and its biological functions in life forms without nervous systems. Life Sci 80:2206-2209

Kleessen B, Sykura B, Zunft HJ, Blaut M (1997) Effects of inulin and lactose on fecal microflora, microbial activity, and bowel habit in elderly constipated persons. Am J Clin Nutr 65:1397-1402

Kumar DK, Choi SH, Washicosky KJ, Eimer WA, Tucker S, Ghofrani J, Lefkowitz A, McColl G, Goldstein LE, Tanzi RE, et al (2016) Amyloid-beta peptide protects against microbial infection in mouse and worm models of Alzheimer's disease. Sci Transl Med 8: 340ra372.

Lakhan SE, Caro M, and Hadzimichalis N (2013) NMDA receptor activity in neuropsychiatric disorders. Frontiers in Psychiatry 4.

Landete JM, De las Rivas B, Marcobal A, Munoz R (2008) Updated molecular knowledge about histamine biosynthesis by bacteria. Crit Rev Food Sci Nutr 48:697-714

LeBlanc JG, Milani C, de Giori GS, Sesma F, van Sinderen D, Ventura M (2013) Bacteria as vitamin suppliers to their host: a gut microbiota perspective. Curr Opin Biotechnol 24:160-168

Lee YK, Menezes JS, Umesaki Y, Mazmanian SK (2011) Proinflammatory T-cell responses to gut microbiota promote experimental autoimmune encephalomyelitis. Proc Natl Acad Sci USA 1:4615-4622

Levi M, Keller TT, van Gorp E, ten Cate H (2003) Infection and inflammation and the coagulation system. Cardiovasc Res 60:26-39

Lim C, Hammond CJ, Hingley ST, Balin BJ (2014) Chlamydia pneumoniae infection of monocytes in vitro stimulates innate and adaptive immune responses relevant to those in Alzheimer's disease. J Neuroinflammation 11:014-0217

Little CS, Joyce TA, Hammond CJ, Matta H, Cahn D, Appelt DM, Balin BJ (2014) Detection of bacterial antigens and Alzheimer's disease-like pathology in the central nervous system of BALB/C mice following intranasal infection with a laboratory isolate of Chlamydia pneumoniae. Front Aging Neurosci 6:304
Lopez MA, Saada EA, Hill KL (2015) Insect stage-specific adenylate cyclases regulate social motility in African trypanosomes. Eukaryot Cell 14:104-112

Macpherson AJ, Harris NL (2004) Interactions between commensal intestinal bacteria and the immune system. Nat Rev Immunol 4:478-485

Macpherson AJ, Uhr T (2004) Induction of protective IgA by intestinal dendritic cells carrying commensal bacteria. Science 303:1662-1665

Marquardt P, Spitznagel G (1959) Bakterielle acetylcholine bildung in kunstlichen Nahrboden. Arzneimittelforschung 9:456-465

Martins IJ, Hone E, Foster JK, Sunram-Lea SI, Gnjec A, Fuller SJ, Nolan D, Gandy SE, Martins RN (2006) Apolipoprotein E, cholesterol metabolism, diabetes, and the convergence of risk factors for Alzheimer's disease and cardiovascular disease. Mol Psychiatry 11:721-736

Masters CL, Simms G, Weinman NA, Multhaup G, McDonald BL, Beyreuther K (1985) Amyloid plaque core protein in Alzheimer disease and Down syndrome. Proc Natl Acad Sci USA 82:42454249

Mulak A, Bonaz B (2015) Brain-gut-microbiota axis in Parkinson's disease. World J Gastroenterol 21:10609-10620

Nursing-Standard (2016) Evidence suggests rosacea may be linked to Parkinson's and Alzheimer's disease. Nursing Standard 30 (39):14

O'Hara AM, Shanahan F (2006) The gut flora as a forgotten organ. EMBO Rep 7:688-693

Otte JM, Rosenberg IM, Podolsky DK (2003) Intestinal myofibroblasts in innate immune responses of the intestine. Gastroenterology 124:1866-1878

Özogul F (2011) Effects of specific lactic acid bacteria species on biogenic amine production by foodborne pathogen. Int J Food Sci Technol 46:478-484

Palmer C, Bik EM, DiGiulio DB, Relman DA, Brown PO (2007) Development of the human infant intestinal microbiota. PLoS Biol $5: 26$

Park SA (2011) A common pathogenic mechanism linking type-2 diabetes and Alzheimer's disease: evidence from animal models. $\mathrm{J}$ Clin Neurol 7:10-18

Parodi A, Paolino S, Greco A, Drago F, Mansi C, Rebora A, Parodi A, Savarino V (2008) Small intestinal bacterial overgrowth in rosacea: clinical effectiveness of its eradication. Clin Gastroenter Hepatol 6:759-764

Pasinetti GM, Wang J, Marambaud P, Ferruzzi M, Gregor P, Knable LA, Ho L (2011) Neuroprotective and metabolic effects of resveratrol: therapeutic implications for Huntington's disease and other neurodegenerative disorders. Exp Neurol 232:1-6

Philpott DJ, Girardin SE, Sansonetti PJ (2001) Innate immune responses of epithelial cells following infection with bacterial pathogens. Curr Opin Immunol 13:410-416

Pignatelli M, Aparicio G, Blanquer I, Hernandez V, Moya A, Tamames J (2008) Metagenomics reveals our incomplete knowledge of global diversity. Bioinformatics 24:2124-2125

Potgieter M, Bester J, Kell DB, Pretorius E (2015) The dormant blood microbiome in chronic, inflammatory diseases. FEMS Microbiol Rev 39:567-591 
Rabot S, Membrez M, Bruneau A, Gerard P, Harach T, Moser M, Raymond F, Mansourian R, Chou CJ (2010) Germ-free C57BL/6J mice are resistant to high-fat-diet-induced insulin resistance and have altered cholesterol metabolism. Faseb J 24:4948-4959

Rajilic-Stojanovic M, Biagi E, Heilig HG, Kajander K, Kekkonen RA, Tims S, de Vos WM (2011) Global and deep molecular analysis of microbiota signatures in fecal samples from patients with irritable bowel syndrome. Gastroenterology 141:1792-1801

Rani V, Deshmukh R, Jaswal P, Bariwal J (2016) Alzheimer's disease: Is this a brain specific diabetic condition? Physiol Behav 1:876-879

Russell WR, Hoyles L, Flint HJ, Dumas ME (2013) Colonic bacterial metabolites and human health. Curr Opin Microbiol 16:246-254

Santa-Maria I, Diaz-Ruiz C, Ksiezak-Reding H, Chen A, Ho L, Wang J, Pasinetti GM (2012) GSPE interferes with tau aggregation in vivo: implication for treating tauopathy. Neurobiol Aging 33:2072-2081

Scheperjans F, Aho V, Pereira PA, Koskinen K, Paulin L, Pekkonen E, Haapaniemi E, Kaakkola S, Eerola-Rautio J, Pohja M et al (2015) Gut microbiota are related to Parkinson's disease and clinical phenotype. Mov Disord 30:350-358

Schwartz K, Boles BR (2013) Microbial amyloids-functions and interactions within the host. Curr Opin Microbiol 16:93-99

Shishov VA, Kirovskaia TA, Kudrin VS, Oleskin AV (2009) Amine neuromediators, their precursors, and oxidation products in the culture of Escherichia coli K-12. Prikl Biokhim Mikrobiol 45:550554

Silva M, Jacobus NV, Deneke C, Gorbach SL (1987) Antimicrobial substance from a human Lactobacillus strain. Antimicrob Agents Chemother 31:1231-1233

Swann JR, Want EJ, Geier FM, Spagou K, Wilson ID, Sidaway JE, Nicholson JK, Holmes E (2011) Systemic gut microbial modulation of bile acid metabolism in host tissue compartments. Proc Natl Acad Sci USA 1:4523-4530

Tan ZS, Beiser AS, Vasan RS, Roubenoff R, Dinarello CA, Harris TB, Benjamin EJ, Au R, Kiel DP, Wolf PA et al (2007) Inflammatory markers and the risk of Alzheimer disease: the Framingham Study. Neurology 68:1902-1908

Thibault H, Aubert-Jacquin C, Goulet O (2004) Effects of long-term consumption of a fermented infant formula (with Bifidobacterium breve c50 and Streptococcus thermophilus 065) on acute diarrhea in healthy infants. J Pediatr Gastroenterol Nutr 39:147-152

Thomas CM, Hong T, van Pijkeren JP, Hemarajata P, Trinh DV, Hu W, Britton RA, Kalkum M, Versalovic J (2012) Histamine derived from probiotic Lactobacillus reuteri suppresses TNF via modulation of PKA and ERK signaling. PLoS One 7:e31951
Tran L, Greenwood-Van Meerveld B (2013) Age-associated remodeling of the intestinal epithelial barrier. J Gerontol A Biol Sci Med Sci 68:1045-1056

Tremaroli V, Backhed F (2012) Functional interactions between the gut microbiota and host metabolism. Nature 489:242-249

Tsavkelova EA, Botvinko IV, Kudrin VS, Oleskin AV (2000) Detection of neurotransmitter amines in microorganisms with the use of high-performance liquid chromatography. Dokl Biochem 372:115-117

von Bernhardi R, Eugenin-von Bernhardi L, Eugenin J (2015) Microglial cell dysregulation in brain aging and neurodegeneration. Front Aging Neurosci 7:231-238

Vulevic J, Drakoularakou A, Yaqoob P, Tzortzis G, Gibson GR (2008) Modulation of the fecal microflora profile and immune function by a novel trans-galactooligosaccharide mixture (BGOS) in healthy elderly volunteers. Am J Clin Nutr 88:1438-1446

Wall R, Cryan JF, Ross RP, Fitzgerald GF, Dinan TG, Stanton C (2014) Bacterial neuroactive compounds produced by psychobiotics. Adv Exp Med Biol 817:221-239

Wang X, Quinn PJ (2010) Endotoxins: lipopolysaccharides of gramnegative bacteria. Subcell Biochem 53:3-25

Wang J, Ho L, Zhao W, Ono K, Rosensweig C, Chen L, Humala N, Teplow DB, Pasinetti GM (2008) Grape-derived polyphenolics prevent Abeta oligomerization and attenuate cognitive deterioration in a mouse model of Alzheimer's disease. J Neurosci 28:6388-6392

Wang Z, Klipfell E, Bennett BJ, Koeth R, Levison BS, Dugar B, Feldstein AE, Britt EB, Fu X, Chung YM et al (2011) Gut flora metabolism of phosphatidylcholine promotes cardiovascular disease. Nature 472:57-63

Wang D, Ho L, Faith J, Ono K, Janle EM, Lachcik PJ, Cooper BR, Jannasch AH, D'Arcy BR, Williams BA et al (2015) Role of intestinal microbiota in the generation of polyphenol-derived phenolic acid mediated attenuation of Alzheimer's disease betaamyloid oligomerization. Mol Nutr Food Res 59:1025-1040

Yaffe K, Lindquist K, Penninx BW, Simonsick EM, Pahor M, Kritchevsky S, Launer L, Kuller L, Rubin S, Harris T (2003) Inflammatory markers and cognition in well-functioning AfricanAmerican and white elders. Neurology 61:76-80

Yano JM, Yu K, Donaldson GP, Shastri GG, Ann P, Ma L, Nagler CR, Ismagilov RF, Mazmanian SK, Hsiao EY (2015) Indigenous bacteria from the gut microbiota regulate host serotonin biosynthesis. Cell 161:264-276

Zuliani G, Ranzini M, Guerra G, Rossi L, Munari MR, Zurlo A, Volpato S, Atti AR, Ble A, Fellin R (2007) Plasma cytokines profile in older subjects with late onset Alzheimer's disease or vascular dementia. J Psychiatr Res 41:686-693 